\title{
INDEX TO VOL. 37
}

(including $C \& R L N e w s$ issues)

Prepared by Eldon W. Tamblyn

ABBREVIATIONS

Standard abbreviations for names of organizations, ALA, ACRL,

LC, etc., are alphabetized as if spelled out. Other abbreviations:

$\begin{array}{ll}\text { appt. } & \text {-appointment } \\ \text { coll.(s) } & \text {-college(s) } \\ \text { comp. } & \text {-compiler } \\ \text { ed. } & \text {-ditor, edition } \\ \text { inst. } & \text {-institute, institution } \\ \text { n (before page numbers) } & \text {-C\&RL News issues } \\ \text { port. } & \text {-portrait } \\ \text { prof. } & \text {-profile } \\ \text { rev. } & \text { - - uniewersiter } \\ \text { univ. } & \end{array}$

\section{A}

A bell, Millicent, port., n7

Abstracting concepts and methods, Borko and Bermier, rev. of, $472-73$

Abstracts, 87-89; $189-92 ; 384-$ 87; $580-82$

"Academic libraries in 1876," Holley, 15-47

"Academic library buildings: a century in review," Orne, 31631

"Academic library statistics released for 1974-75," NCES, n57

Acquisitions, $\mathrm{n} 8-11 ; \mathrm{n} 35-36$; n59-60; n86; n115-18; n139; n174-75; n202-3; n235-36. n274-75; n306-7

Acquisitions (by institution ): Andover-Harvard Theological Library, nl17; Bryn Mawr Coll. n203; Bucknell Univ., n235. CUNY: City Coll., n274-75. Eastern Montana Coll., n116; Elmira Coll., n86; Florida State Univ., n9; Francis Marion Coll., n10: Georgetown Univ., n174, n202; Goucher Coll., n175; Hofstra Univ., n274; Indiana State Univ., n8, n235; LC. n10, n235-36; Muhlenberg Coll. n115; New York Botanical Garden, n59-60: NYPL, nl18; Point Loma Coll., n175; San Diego State Univ., n306. Southeastern Massachusetts Univ., n116; Stanford Univ., n10: SUNY; Coll, at Geneseo, n306-7; SUNY: Stony Brook, n307; Temple Univ, n275; Trinity Coll., n86; Tulane Univ., n115-16; Univ, of Ala- bama, n202; Univ. of Arizona, n174, n202-3; Univ. of California: Davis, n8-9; Irvine, n174; Riverside, n115; Santa Cruz, n236; Univ. of Idaho, $\mathrm{n} 9$; Univ. of Illinois, n203, n236; Univ, of Kansas, nI1617; Univ. of Missouri: St. Louis, n35-36; Univ. of New Mexico, n139, n235; Univ. of Rochester, n174-75; Univ. of Tennessee, n139, n202; Univ. of Texas, n174, n306; Univ. of Texas: Austin, n8, n35; Univ. of Tulsa, n59, n202; Univ, of Virginia, $n 9-10, \mathrm{n} 35$ Univ. of Waterloo, nll7-18;

Univ, of West Florida, n306; Wake Forest Univ., n115; Washington Univ., n274, Western Michigan Univ., n36

Acquisitions (by subject, author. or title): Abbot Obrecht collection, n36; American Indian collection (Shleppey), n59

American Political Science Association archives, n174; Art books and catalogs (Eisendrath) n35-36: Arundel Library, n10; Atlas ameriquain septentrional, n203; Author collections of 20th-century English and American literary figures, nl15: Bibles and early medical books (Bopp), n86; Black Sparrow Press archives, n235; Books on India, n306; Brahe, Historia coelestis, n306; C. Connolly library, n202; Calepinus, Dictionarium, $\mathrm{n} 8 ; \mathrm{Ca}$ nadian recordings of music and the spoken word, nI 18: Collection on bookplates (Midlo), nl16; Commission, society and committee records, n275; Custer Collections, nl16; D. H Lawrence Collection (Martin), n59; Dance and opera (Crapo), n117-18; Davies, ed. Documents of the American Revolution, 1770-1783, n23536; Diário de Notícias, nl16; Eberstadt Collection, n8; Ecuadorian government documents, n174; Firehouse Theatre, n89; G. E. Wright library of biblical archaeology, n174, n2023; G. R. Bidwell papers, n274; Galston-Busoni Archives and Galston Music Collection, n139; German and international law journals, n202: Greene, Graham, n59; Irish literature (Healy), n10; J. Austen memorabilia (Burke), nl75; I. G. Meem library, n139; Jones, Robert E., Congressman, n202; L. Butler library, n235; L. H. Morgan collection (Orange) n274; Living Theatre, n89; Long Island R. R. photographs, n307; M. Bieber library, n116; M. H. Beyle collection (Alciatore), nI 15-16. Masefield, John, n203; Mencken, H. L., n306; Meyer, Eugene, nl0; Muhlenberg collection of historic documents, 115. Nez Perce hymnal, n9. O. Jonas Music Collection, ni15; Olympic Games archives (Brundage), n236; Orsetti family archives (Rubinstein) n116-17; Palou's life of Father Junipero Serra, n236: Phonographic Library of Contemporary Poets, n275; Platearius, Circa instans, n59-60; Plinius 
Secundus, Historia naturalis, n306; R. Graves-L. Riding Collection, n202; Rare books (Lande), n86; Revolutionary Virginia broadside, n9-10, n35; St. John d'el Rey Mining Co., n35; Scottish collection, n9; Socialist Party Papers, n235; Steinhaus, Arthur H., n202; Suffrage and reform movements, n174-75; U.S. Volleyball Association archives on microfiche, n174; Universalist Historical Society library, n1 17; Visscher map, n274; Vocal music collection, n274; Wadsworth Homestead papers and photographs, n306-7; Wesleyan Arminian materials, n175; West Florida and the Gulf Region, $\mathrm{n} 306$

Acquisitions from the Third World: papers of the Ligue des bibliotheques européennes de recherche seminar 17-19 September 1973, Clarke, ed., rev. of, 80

"Acquisitions overkill in science collections-and an alternative," Opello and Murdock, 452-56

Adamovich, Shirley Gray, ed, Reader in library technology, rev. of, 478

Adams, Velma Lee, retired, n95

The administrative aspects of education for librarianship: a symposium, Cassata and Totten, eds., rev. of, 180-81

The age of Jewett: Charles Coffin Jewett and American librarianship, 1841-1868, Harris, ed., rev. of $174-75$

Ainsworth Rand Spofford: bookman and librarian, Cole, ed. rev. of, 375

Alexander, Norman D., prof. \& port., n259

"Allocating the book budget: model," Kohut ( $C \dot{L} L \mathrm{R}$ 35: 192-99), comment, 369

"Allocating the book budget: an economic model" Gold ( $C \& R L$ $36: 397-402$ ), letter to the ed., 369

"Allocating the book budget: equity and economic efficiency, Kohut and Walker (CoRL 36 : 403-10), comment, 369

"American Historical Association endorses Joint statement on faculty status," n311

ALA, "Resolution on racism \& sexism awareness," n287

ASIS, Information revolution: proceedings of the 38th ASIS annual meeting, Boston, Massachusetts, October 26-30, 1975, rev. of, 474-75

ASIS, Information roundup: proceedings of the 4th ASIS mid year meeting, Portland, Ore gon, May 15-17, 1975, rev. of, 474-75

Anderson, Charles B., ed., Book selling in America and the world: some observations of recollections in celebration of the 75th anniversary of the American Booksellers Association, rev, of $177-78$

Anderson, Edwin Hatfield, port., 337

Anderson, Le Moyne W." "The Association of College and $\mathrm{Re}$ search Libraries: a report of the membership survey, 1975," nl 11-13

Annual review of information science and technology, v.10, 1975, Cuadra, ed., rev. of, 561-62
Appointments, n23-25; n47; n75 77 ; n95; n127-28; nI59-61; n191; n224-25; n259-61; ก291-92; n323-24

ACRL, Ad Hoc Committee to Revise the 1959 Standards for college libraries, "Working papers available from ERIC," $n 268$

ACRL, additional nominees for offices, 1976/77, n32

ACRL, Agriculture and Biological Sciences Section, "Renewable resources program for ABSS," n138

ACRL, "Annual report of the president 1975-76," n167-70

ACRL Bibliographic Instruction Task Force, "Draft guidelines for bibliographic instruction in academic libraries," n30I

ACRL, Board of Directors, midwinter meeting, Chicago, Jan. 18-24, 1976, "Highlights," n55-56; policy statement on the M.L.S, degree (CむRL News $36: 69$ ), comments, n57, n188, n252

ACRL, Books for college libraries: a core collection of 40,000 titles, $2 \mathrm{~d}$ ed, rev of, 71-74

ACRL, Committee on Academic Status, Faculty status for academic librorians: $a$ history and policy statements, rev. of, 176 77

ACRL, Committee on Appointments and Nominations "ACRL seeks volunteers," n267-69

ACRL, Committee on Legislation, "Report on copyright and HEA amendments," n138, n155-56

ACRL, Eastern New York Chapter, "Copyright law-1976," n171-72; "Retrenchment in higher education: implications for libraries," n6-7; videotape available n275

ACRL Education and Behavioral Sciences Section, letter to members, n31-32

ACRL, midwinter meeting, Chicago, Jan. 30-Feb. 5, 1977 tentative schedule of meetings, n304-5

ACRL, New England Chapter "NELINET-ACRL/NEC joint meeting and conference," n36

ACRL, Rare Books and Manuscripts Section, Committee on Manuscripts Collections, "Draft statement on the reproduction of manuscripts and archives for commercial purposes" (C\&RL News 36:96-97), proposed revisions, n273, n289; "Statement on access to original research materials in libraries, archives. and manuscript repositories" (C\&RL News 35:114), proposed revisions, n99-101; approved statement, n272-73; "Statement on the reproduction of manuscripts and archives for noncommercial purposes" (CURL News 35:115), proposed revisions, nI02-4; approved statement, n271

ACRL, "Salaries of academic librarians 1975/76,"n231-34

ACRL, Subcommittee on Goals, Priorities, and Structures, "The Association of College and Research Libraries: a report of the membership survey, 1975," n111-13

"The Association of College and Research Libraries: a report of the membership survey, 1975,"
ACRL, Subcommittee on Goals, Priorities, and Structures, n111-13

"ACRL and ALA representatives at academic ceremonies and meetings," $n 173$

ACRL/AAC/AAUP, "Statement on faculty status of college and university librarians" (CURI News 35:26), "Organizations endorsing the statement on faculty status," n33; esdorsement, n311

"ACRL at the "76 conference," n220-21

"ACRL candidates, 1977 elections," n302-3, n320

"ACRL cassette on evaluating library instruction," n251

"ACRL emphasizes ethnicity theme at Chicago conference," n85

"ACRL internship program," n135-36

"ACRL officers for 1976/77," n199-201

"ACHL seeks volunteers," ACRL, Committee on Appointments and Nominations, n267-69

"ACRL Standards working papers available from ERIC," n268

Auger, Charles P., ed., Use of reports literature, rev, of, 178-

Awards, n175-77; n203-4

\section{$\mathrm{B}$}

Bailey, Martha J., "Some effects of faculty status on supervision in academic libraries," 48-52

Baker, Mary, retired, n225

Barber, Lynn, "Report on the conference on retrenchment in higher education: implications for libraries," n6-7; videotape available, n275

Barksdale, Robbie, retired, n324

Barnes, Mary W., retired, nl61

Barr Keith, and Line, Maurice eds., Essays on information and libraries, rev. of, 275-76

Becker, Joseph, and Hayes, Handbook of data processing for libraries, $2 \mathrm{~d}$ ed., rev. of, 170-71

Beeler, Richard J., ed., Evaluating library use instruction: papers presented at the University of Denver Conference on the Evaluation of Library Instruction, December 13-14, 1973 rev, of, 280-81

Bennett, Fleming, retired, nl61

Bergman, Sherrie S., rev. (Women in a woman's profession), 74-76; rev. (Women in librarianship) 74-76

Bernier, Charles L., and Borko, Abstracting concepts and methods, rev. of, 472-73

Berninghausen, David $K$. The fight from reason: essays on intellectual freedom in the academy, the press, and the $l i$ brary, rev. of , 77-78

"Beverly Lynch resigns as ACRL Executive Secretary," Dunlap, n299

A bibliography of Africana, Panofsky, rev, of (CぬRL 36:51920), comment, 167; response, 167

Bibliography: tiger or fat cat? Dunkin, rev, of 278

Bishop, William Warner, port.,

Black. Donald V,, and Cuadra, Carlos A., Directory of aca- 
demic library consortia, $2 \mathrm{~d}$ ed., rev. of, 563-64

Black literature resources: analysis and organization, Clack, rev, of, $471-72$

Bloomquist, Harold J., retired, n225

Bond, Julian, port., n137

Book reviews, 71-82; $170-86$; $275-82 ; 373-80 ; 469-80 ; 556-$ 74

Book selection: principles and procedures, Lunati, rev. of, 379-80

Books for college libraries: a core collection of 40,000 titles, $2 \mathrm{~d}$ ed., ACRL, rev, of, 71-74

Bookselling in America and the world: some observations \& recollections in celebration of the 75th anniversary of the American Booksellers Association, Anderson, ed rev, of, 177-78

Borko, Harold, and Bernier. Charles L., Abstracting concents and methods, rev. of, 472-73

Bramley, Gerald, World trends in library education, rev. of, 171 73

Brister, Marjorie, retired, n324

Broadus, Robert, rev. (Book selection), 379-80

Bruer, J. Michael, rev. (Acquisitions from the Third World), 80

Budington, William S., "To enlarge the sphere of human knowledge": the role of the independent research library," 299-315; comment, 552

Burckel, Nicholas C., rev. (Modern archives and manuscripts), 478-79

Butler, Brett, and Martin, eds. Library automation: the state of the art II, rev. of, 375-77

\section{$\mathrm{C}$}

Campbell, Malcolm J., ed., Manual of business library practice, rev. of, 473-74

Carroll, C. Edward, rev. (The shaping of American library education), 173-74

Case, Sara, "Inside Washington," n58

Casellas, Elizabeth, retired, n324

Cassata Mary B. and Totten, Herman L., eds., The administrative aspects of education for librarianship: a symposium, rev. of, 180-81

Catalogue provision in libraries of colleges of advanced education, Stecher, rev. of, $\mathbf{5 6 8}$

Cave, Roderick, Rare book librarianship, rev, of , 476-77

"Celebrate," Johnson, editorial, 3

Censorship in public libraries in the United Kingdom during the twentieth century, Thompson, rev. of, 565-66

Censure and censorship: impediments to free publication in the Age of Enlightenment, Shackleton, rev, of, 78

"A century abroad," Vosper, 514-30

"A century of academic librarianship, as reflected in its literature," Kaser, 110-27; comment, 371-72

"A century of cooperative programs among academic libraries," Weber, 205-21

Chen, Robert P., letter to the ed., nl14

Chisholm, Margaret, and McDonald, Dennis D., eds., Reader in 'media, technology and $l i$ - braries, rev. of, 563

Christian, Roger W., The electronic library: bibliographic data bases 1975-76, rev. of, 76-77

Churchwell, Charles D., The shaping of American library education, rev, of, 173-74

"Circulation and its relationship to the book collection and academic departments," Jenks, 145-52

Citron, Helen R., rev. (Catalogue provision in libraries of colleges of advanced education), 568

Clack, Doris H., Black literature resources: analysis and organization, rev of, 471-72

Clarke, D. A., ed., Acquistions from the Third World: papers of the Ligue des bibliotheques européennes de recherche seminar 17-19 September 1973 rev. of, 80

Classification and indexing in science, 3d ed., Vickery, rev. of, $179-80$

Cohen, Nina T., prof. \& port., n223-24

Cohn, Williarr-L., "An overview of ARL directors, 1933-1973," $137-44$

Cole, John Y., ed., Ainsworth Rand Spofford: bookman and librarian, rev. of, 375

"Collective bargaining and academic librarians: a review of the decisions of the NLRB," Schmidt, $\mathbf{n} \mathbf{l}-3$

Collective bargaining in libraries. Schlipf, ed., rev, of, 377

Coman, Edwin T. Jr, rev, (Manual of business library practice), 473-74; rev. (Specialised information centres), 473-74

Communication, knowledge and the librarian, McGarry, rev, of, 182

The community college library. Veit, rev. of, 183-84

Cook, C. Donald, rev, (Bibliography: tiger or fat cat?), 278

Cook, Margaret $\mathrm{G}$., The new library key, $3 \mathrm{~d}$ ed., rev. of, 278 80

Coordination: concept or reality? A study of libraries in a university system, Myrick, rev. of, 469-70

"Coping with budget adversity: the impact of the financial squeeze on acquisitions," Reid, 266-72

"Copyright and HEA amendments," report, ACRL, Committee on Legislation, n138. n155-56

"Copyright law-1976," ACRL, Eastern New York Chapter. n171-72

Corporate headings: their use in library catalogues and national bibliographies, Verona, rev. of, 480

Cossar, Bruce, rev, (Interlibrary Loan in Canada), 572-73; rev. (A survey and interpretation of the literature of interlibrary loan), 572-73

CLR, Fellowship Committee "Eighth class of CLR fellows selected," n136

"CLA annual report," n64

Cowley, John, ed." Libraries in higher education: the user approach to service, rev. of, 277

Crix, F. C., Reprographic management handbook, rev. of, $569-70$

Crowley, John V., appt. \& port., n300; rev. (Faculty status for academic librarians) 176-77

Cuadra, Carlos A., ed., Annual review of information science and technology, v.10, 1975, rev, of 561-62

Cuadra, Carlos A., and Black, Directory of academic library consortia, $2 \mathrm{~d}$ ed., rev, of, 563 64

Cutter, Charles A., port., 433

\section{D}

Dain, Phyllis, rev. (Public libraries as culture and social cen ters), 175-76

Danton, J. Periam, letter to the ed. 371-72

Davies, D. W, Public libraries as culture and social centers: the origin of the concept, rev. of, $175-76$

Deaths, n77; n128; n161; n191; n261

Delavenay, Emile, For books, rev. of, $177-78$

DePriest, E. Raleigh, retired, n225

"The development of collections in American university libraries," Edelman and Tatum, 22245

Dewey, Melvil, port., 437

Diaz, Albert James, ed., Microforms in libraries: a reader, rev. of, $81-82$

Directory of academic library consortia, $2 \mathrm{~d}$ ed., Black and Cuadra, rev. of, 563-64

Document retrieval systems: factors affecting search time, Montgomery, rev, of, 181-82

Donahue, Margaret M., retired, n225

Donohue, Mildred D., retired. $n 225$

Dorr, Ralze W., letter to the ed. n188; comment, n252

Downs, Robert B.." "The role of the academic librarian, 1876 1976," 491-502

Downs, Robert B, and Keller, Clara D., How to do library research, $2 \mathrm{~d}$ ed., rev. of, $278-80$

"Draft guidelines for bibliographic instruction in academic libraries," ACRL Bibliographic Instruction Task Force, n301

"Draft statement on the reproduction of manuscripts and archives for commercial purposes," ACRL, Rare Books and Manuscripts Section, Committee on Manuscripts Collections, n273, n289

Drake Miriam A. "Forecasting academic library growth," 5359

Drucker, Peter F., "Managing the public service institution," 4-14

Duckett, Kenneth W., Modern manuscripts: a practical manual for their management, care and use, rev. of, 276-77

Duignan, Peter, rev. (A bibliog raphy of Africana) (CURL 36 . 519-20), comment, 167; response, 167

Dukes, Eugene D., letter to the ed. (C\&RL News 36:349), comments, n57, n188, n252

Dunkin, Paul S., Bibliography: tiger or fat cat? rev, of, 278

Dunlap, Connie R. "Beverly Lynch resigns as ACRL Executive Secretary," n299; "Library services to the graduate community: the University of Michigan," 247-51; "Organizational patterns in academic libraries, 1876-1976," 395-407. port., n 199 


\section{CHECKLIST}

\section{OF UNITED STATES} PUBLIC DOCUMENTS 1789-1975

THIS DUAL-MEDIA EDITION CONTAINS NOTHING LESS THAN THE COMPLETE SHELFLIST OF GPO'S PUBLIC DOCUMENTS LIBRARY - WITH ITS CARD CATALOGS ON MICROFILM AND WITH TWENTY-ONE HARDCOVER INDEX VOLUMES.

\section{CHECKLIST ' 75}

-contains some 1.3 million full bibliographic entries for more than 2 million U.S. Government publications issued from 1789 through 1975.

-is arranged on microfilm according to the Su Docs Classification System but is also accessible by title and by the names of government author-organizations via its printed index volumes. Accordingly, it is a primary source for the bibliographic data needed in identifying and ordering copies of out-of-print U.S. Government publications.

-includes, in one place, all the bibliographic data contained in the 1909 Checklist (1789-1909), the Documents Catalogues (1893-1940) and the Monthly Catalogs (1895-1975), plus entries for thousands of publications never listed in any of those pubtications.

- expands and updates Checklist ' 70 with the addition of more than 100,000 new entries accumulated over the past $5 \frac{1}{2}$ years.

\section{UPDATING CHECKLIST '70}

During the years since we first began filming Checklist '70, the U.S. Government has published more than 100,000 documents, many on such vital topics as the Viet Nam War, Watergate, recession, detente, fuel shortages, agripower, terrorism, environmental problems, consumer protection, foreign policy realignment, and of course, investigations of everything from intelligence operations to aerosol sprays. The cards desscribing these new additions were interfiled into the Shelflists in Su Docs Class order, and re-filming operations began when the file was current as of January 1, 1976. Those new entries which involved changes in govemment author-organizations were picked up and listed in supplementary sections added to the five original indexes.

\section{THE PROBLEM LONG-OUT-OF-PRIN1 DOCUMENTS HA}

Now that the world's largest retrospective collection o GPO to the National Archives-and re-shelved in 's libraries, for the first time, can order facsimiles or mid U.S. Government documents published since $178 \mathrm{~g}$

\section{CHECKLIST '75 AND ITS NEW INDEXES WERE} AND ORDER THE

The collection, of course, is GPO's Public Documents Library, long recognized as the most complete U.S. Government documents collection because of its statutory retention requirements. During 1972, all pre-1971 materials were moved to the Printed Archives Branch of the National Archives and Records Service, whose staff has just recently completed re-shelving them in Superintendent-of-Documents Classification order (the same arrangement used in the Shelflist card files). Meanwhile, the materials for 1971 and 1972 have recently been received and are now in the re-shelving process. The complete card catalogs and the later documents are still kept at GPO.

As GPO had kept the Public Document collection closed during its decades of custodianship, the sudden availability of facsimiles and microfilm copies under the usual National Archives sales terms must be considered an important new step toward the wider and more effective reference use of U.S. Government documents.

USE THIS COUPON TO ORDER AT PRE-PUBLICATIC

To: The U.S. Historical Documents Institute, Incorporated 1911 Fort Myer Drive, Arlington, Virginia 22209

Please record our order for:

The "Standard" Dual Media Edition of CHECKLIST OF UNIT 118 silver-halide microfilm reels plus 5 hardcover Index volur (add $\$ 300$ for $35 \mathrm{~mm}$ microfilm and $\$ 250$ for $16 \mathrm{~mm}$ cartricges if c

The CUMULATIVE TITLE INDEX TO U.S. PUBLIC DOCUME volumes.

The Combined Dual Media Edition, containing the "Standard 118 reels plus 21 hardcover index volumes (note $\$ 225$ savings)

$\square$ The Standard Index volumes only (set of five volumes).....

$\square$ Index I, Superintendent of Documents

Classification Number Index of U.S.

Government Author-Organizations, 1789-1975 ........\$53

Index II, U.S. Government Author-

Organization Index, 1789-1975 $\$ 53$

$\square$ Index III, Departmental Keyword Indexes to U.S. Government AuthorOrganizations, 1789-1975 . .553

Please send us your free brochure containing further informa

Name

Address 


\section{OF ACQUIRING}

\section{U.S. GOVERNMENT}

\section{S BEEN SOLVED!}

U.S. Government documents has been moved from uperintendent of Documents Classification orderofilm copies of some 2 million previously out-of-print

\section{DESIGNED TO HELP YOU IDENTIFY, SELECT, SE DOCUMENTS}

It also means that the identification of documents by Su Docs Class Numbers has become more important than ever-and this of course, is where the Chocklist ' 75 indexes will play their most important part.

Libraries having their own substantial documents collection arranged in Su Docs Class order, or those which find it convenient to order or borrow copies of documents from their local Regional Depository Libraries will, of course, also find the Checklist Indexes invaluable in retrieving their documents without having to order copies from National Archives.

The important point, however, is that their existing systems are now backed up by the potential availability of copies of even the oldest and rarest documents through the Public Documents Library.

Orders and inquiries to National Archives should be addressed to C. F. W. Coker, Chief, Public Archives Branch, National Archives \& Records Service, Washington, D C. 20408.

N PRICES - OR TO RECEIVE A FREE BROCHURE.

STATES PUBLIC DOCUMENTS, $1789-1975$ es, excluding the Cumulative Title Index esired)

NTS, 17139-1975, in 16 hardcover

Edition and the Cumulative Title Index,

\section{$\$ 325$}

Index IV, U.S. Government Serial Titles, 1789-1975 $\$ 75$

Index V, Master Keyword Index to the Publication Issuing Offices of the U.S. Government, 1789-1975 $\$ 75$

on about Checklist ' 75 and its indexes.

\section{CUMULATIVE}

TITLE INDEX TO

\section{U.S. GOVERNMENT PUBLICATIONS}

\section{9-1975}

THE LARGEST AND MOST COMPREHENSIVE TITLE INDEX TO U.S. GOVERNMENT DOCU. MENTS EVER PRODUCED IN ANY FORMAT.

Here is the long awaited single-alphabet listing of all titles contained in the shelflists of the Public Documents Library - the "Million Title" index to CHECKLIST OF UNITED STATESDOCUMENTS, 1789-1975.

Now, for the first time, librarians with documents collections of every size and type will be able to identify the Superintendent of Documents Classification Numbers for more than one million titles published by the U.S. Government over the past 186 years-and, also for the first time, be able to use these Su Docs Class Numbers to order facsimile or microfilm copies of specific documents from a centralized source.

The massive Cumulative Title Index can be used either by itself to order documents when the title, date, and Su Docs Numbers are sufficient identification; or in conjunction with Checklist ' 75 , when it is desirable to learn complete bibliographic data on a publication prior to ordering copies (e.g. to find out the numbers of pages which will have to be copied @ 15c apiece, or to isolate specific numbers or parts of series).

In addition to the title, Su Docs Class Number, and the date of the information in the document, each entry also gives the microfilm reol number on which the full description can be found in Checklist ' 75 .

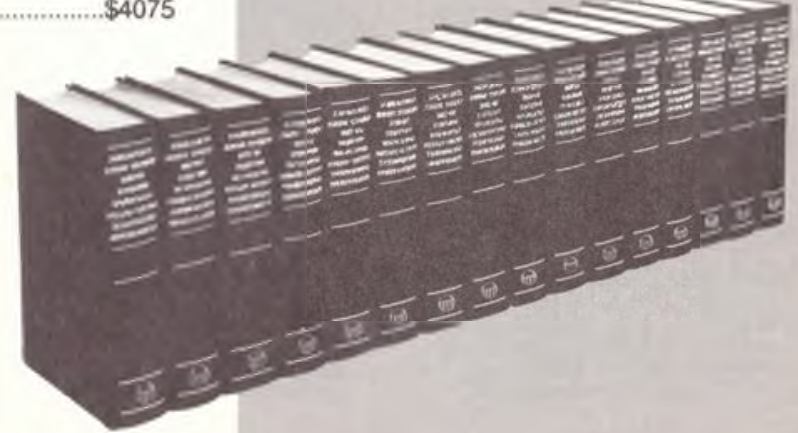

in sixteen

hardcover volumes $\left(81 / 2 " \times 11^{\prime \prime}\right)$ compiled by Daniel Lester and Sandra Faull 
Edelman, Hendrik, and Tatum, G. Marvin, Jr., "The development of collections in American university libraries," 22245

Edgar, Neal L., letter to the ed., n114

Edwards, Ralph M., The role of the beginning librarian in university libraries, rev, of, 47778

"Eighth class of CLR fellows selected," CLR, Fellowship Committee, n136

The electronic library: bibliographic data bases 1975-76, Christian, rev. of, 76-77

Ellsworth, Diane J., and Stevens, Norman D., eds. Landmarks of library literature, $1876-1976$. rev. of, 568-69

Essays on information and libraries, Barr and Line, eds., rev. of, $275-76$

"Estimating lost volumes in a university library collection," $\mathrm{Ni}$ land and Kurth, 128-36

Evaluating library use instruction: papers presented at the University of Denver Conference on the Evaluation of Library Instruction, December 13-14 1973. Beeler, ed., rev. of, $280-$ $8 \mathrm{I}$

Evans, Frank B., comp., Modern archives and manuscripts: $a$ select bibliography, rev. of, 478 79

Evans, Glyn T., rev. (Coordination: concept or reality? $\left.{ }^{2}\right), 469$ 70

\section{F}

"Faculty Exchange Center," n232

Faculty status for academic librarians: a history and policy statements, ACRL, Committee on Academic Status, rev. of, 176 77

"Faculty status for librarians," videotape available, $\mathrm{n} 125$

Faibisoff, Sylvia G. rev. (The electronic library), 76-77; rev. (Library networks' $74-75$ ) 76 77

Fair, Judy H. rev. (Ainsworth Rand Spofford), 375

Fang, Josephine Riss, rev, (World trends in library education) 171-73

Fairwell to Alexandria: solutions to space, growth, and performance problems of libraries, Gore, ed., rev. of, 556-58

Fellowships, n60; n118; n236

Ferguson, Douglas, rev. (Information systems and networks) 82

Fielder, Sybil, retired, n191

Flanagan, Cathleen, rev. (Media in higher education, the critical issues), 564-65

Flener, Jane G., port., n200

The flight from reason: essays on intellectual freedom in the academy, the press, and the $l i$ brary, Berninghausen, rev, of, 77-78

For books, Delavenay, rev, of, $177-78$

"Forecasting academic library growth," Drake, 53-59

Foster, Donald L., Managing the catalog department, rev. of $281-82$

Fowler, Julian S., deceased, n77
Freides, Thelma, letter to the ed. I67; response, 167

Friesen, M., and McInnes; StuartStubbs, Interlibrary loan in Canada: a report of a survey, rev. of $572-73$

Friesen, M. and McInnes; StuartStubbs; Nichol, A survey and interpretation of the literature of interlibrary loan, rev. of, 572-73

"From Cutter to computer: technical services in academic and research libraries, 1876-1976," Tuttle, 421-51

Funk, Roger L, rev, (Censorship in public libraries in the United Kingdom during the twentieh century), 565-66

\section{$G$}

Galloway, R. Dean, letter to the ed. 551 ; response, 551-52

Gelfand, Morris A., retired, n225

George, Mary W. rev. (How to do library research, $2 \mathrm{~d}$ ed.) 278-80; rev. (The new library key, 3d ed. ), 278-80

German Research Sopiety, Library Committee, Uberregionale Literaturversorgung von Wissenschaft und Forschung in der Bundesrepıblik Deutschland: Denkschrift, rev, of, $182-$ 83

Gibson, Edward, rev, (Libraries and work sampling), 175

Giles, Louise, "Annual report of the president 1975-76," n16770 ; "The impact of the new dues structure," n83-84; port., n83

Gillies, Thomas D., rev. (Use of reports literature), 178-79

GitteIsohn, Marc, rev. (Bookselting in America and the world), 177-78; rev. (For books), 17778

Gold, Steven D., "Allocating the book budget: an economic model" ( $C \& R L$ 36:397-402). letter to the ed., 369

Goldstein, Seth, ed., Library networks '74-75, rev, of, 76-77

Goode, Annie R., retired, n292

Goodell, John S., Libraries and work sampling, rev, of, 175

Gore, Daniel, ed., Farewell to Alexandria: solutions to space, growth, and performance problems of libraties, rev. of, 556 58

Gossage, Wayne, "Letter to ACRL EBSS members," n3132

Grants, n60; n86-87; n119; n177; n204-6; n236-38; n275-76. n307-8

Grants (by grantee): American Antiquarian Society, n308; Barrow Preservation Research. n119; Bruntjen, Scott, n177; CUNY: City Coll n275: Cornell Univ., n204-6, n276; DePauw Univ., n204-6; Dodson, Suzanne, n308; Earlham Coll. n204-6; Gothberg, Helen, n237-38; IFLA n60; Johnson, Edward R., n206; Kansas City area libraries, n238; Kelker. Signe, n177; Lawrence Univ,, n204-6; Lewis and Clark Coll., n204-6; LC, n60-61, n119; Mann, Stuart H., n206; Michigan Library Consortium, n307: North Carolina Agricultural and Technical Univ., n204-6; Oregon State Univ. n204-6: Presbyterian Coll., n204-6;
Princeton Univ. n307-8; Radcliffe Coll., n275-76; Rhode Island Coll., n236-37; Simmons Coll., n276; SUNY: Coll. at Potsdam, n204-6; Univ. of British Columbia, n308; Univ. of Connecticut, n280; Univ. of Illinois, n60; Univ. of New Hampshire, n204-6; Univ. of Pitsburgh, n237; Univ. of South Carolina, n204-6; Valunas, Madelyn, n177; West Georgia Coll., n204-6; WILCO, n237; Wheaton Coll., n177

Grants (by grantor): Association for Asian Studies, CORMOSEA, Reference Aids Subcommittee, n86-87; AALS, n177; CLR, n60-61, n119, n204-6, n276, n280, n307-8; Japan Foundation, n275; Japan Foundation Library Support Program, n177; Kellogg Foundation, n276, n307; Missouri State Library, n238; NCLIS, n237; NEH, n119, n308; National Historical Publications and Records Commission, n236-37; NSF, n177; Rockefeller Foundation, n'275-76; USOE, n237-38

Griffith, Alice B., rev, (The community college library) 183-84

Grondin, François $\mathbf{X}$., deceased, $n 128$

"The growth rates of major academic libraries: Rider and Purdue reviewed," Leach, 531-42

Grundt, Leonard, rev. (Directory of academic library consortia, 2d ed. ), 563-64

Guide to Polish libraties and archives. Lewanski, comp., rev. of, $378-79$

Guide to the research collections of the New York Public Library, Williams, comp., rev of, 373-74

Guido, John F., rev, (Rare book librorianship), 476-77

Guild, Reuben A., port, 31

Gwinup, Thomas, letter to the ed. n57; comments, n188, n25.

\section{$\mathrm{H}$}

"HEA amendments," report, ACRL, Committee on Legislation, n138, n155-56

Hallenberger, Mrs, Loren, retired, $\mathrm{n} 225$

Handbook of data processing for libraries, $2 \mathrm{~d}$ ed. Hayes and Becker, rev. of, 170-71

Harrer, G. A. rev, (Libraries and the challenge of change), 184-85

Harris, Jessica L, rev, ( $A b$ stracting concepts and methods), 472-73

Harris, Michael H., ed., The age of Jewett: Charles Coffin Jewett and American librarianship. 1841-1868, rev. of, 174-75

Harvey, Joan M., Specialised information centres, rev. of, 47374

Harvey, John F, and Parr, Mary, "University library search and screen committees," 347-55; comment, 551; response, 551-

Hassall, A. G., and Hassall. W. O. Treasures from the Bodleion Library, rev. of, 570-72

Hassall, W. O. and Hassall. Treasures from the Bodleian 
Library, rev, of, 570-72

Hayes, Robert M., and Becker, Joseph, Handbook of data processing for libraries, $2 \mathrm{~d}$ ed., rev, of, 170-71

Healy, Burbara R., rev, (Reader in library technology), 478

Heim, Kathleen M., rev. (Libraries in higher education), 277

Hirsch, Felix E., rev. (Standards for library service), 78-79

Historic preservation, Rath and O'Connell, eds., rev, of, 378

Holland, Maurita Peterson, "Serial cuts vs. public service: a formula," 543-48

Holley, Edward G." "Academic libraries in $1876, " 15-47$

Hopkins, Jeannette Hitchcock, deceased, $\mathrm{n} 19 \mathrm{I}$

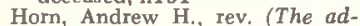
ministrative aspects of education for librarianship), 180-81

How to do library research, $2 \mathrm{~d}$ ed, Downs and Keller, rev, of, 278-80

Hunt, Donald R., prof. \& port. n127

\section{I}

Immroth, John Phillip, deceased, $\mathrm{n} 161$

"The impact of the new dues structure," Giles, n83-84

"The influx of Ph.D.s into librarianship: intrusion or transfusion?" Miller, 158-65

Information for action: from knowledge to action, Kochen. ed., rev. of, 566-68

Information retrieval, British \& American, 1876-1976, Metcalfe, rev. of, 479-80

Information revolution: proceedings of the 38th ASIS annual meeting, Boston, Massachusetts, October 26-30, 1975 . ASIS, rev. of, 474-75

Information roundup: proceedings of the 4th ASIS mid-year meet ing, Portland, Oregon, May 15 17,1975 , ASIS, rev. of, $474-$ 75

Information systems and networks. Eleventh annual symposium, March 27-29, 1974, Sherrod, ed., rev. of, 82

Ingram, K, E., and Jefferson, Albertina A., eds., Libraries and the challenge of change, rev. of, 184-85

"Inside Washington," Case, n58

Interlibrary loan in Canada: a report of a survey, Stuart-Stubbs, Friesen and McInnes, rev, of, $572-73$

Interlibrary loan policies directory, Thomson, rev, of (C\&RL $36: 429)$, comment, 167

\section{J}

Jefferson, Albertina A, and Ingram, eds., Libraries and the challenge of change, rev. of, 184-85

Jenks, George M "Circulation and its relationship to the book collection and academic depart. ments," 145-52

Jernigan, Ollie Mae, retired, n292

"John Crowley named editor of Cd RL News," n 300

Johnson, Richard D., "Celebrate," editorial, 3; "Reading, writing," editorial, 109

\section{K}

Kaplan, Louis, "The literature of participation: from optimism to realism" (C\&RL 36:473-79), comment, $369-71$; response, 371

Karlson, Marjorie, rev, (Interlibrary loan policies directory) (CURL 36:429), comment, 167

Kaser, David, "A century of academic librarianship, as reflected in its literature," $110-27$; comment, 371-72; rev. (Landmarks of library literature, 18761.976), 568-69

Keller, Clara D. and Downs How to do library research, $2 \mathrm{~d}$ ed., rev. of, 278-80

Kelly, Judy, letter to the ed., 167

Kemler, Doris, retired, n324

Kenney, Louis A., rev. (Microforms in libraries), 81-82

"Keyes D. Metcalf," Weber, 346

Knowlton, Ruth B., retired, n292

Kochen, Manfred, ed., Information for action: from knowledge to action, rev, of 566-68

Koel, Ake I., rev. (Corporate headings), 480

Kohut, Joseph J., "Allocating the book budget: a model" (CURL 35:192-99), comment, 369

Kohut, Joseph J., and Walker, John F., "Allocating the book budget: equity and economic efficiency" (CむRL 36:40310), comment, 369

Kribs, Anna, retired, n324

Krieg, Clarice E, retired, n261

Kudrik, Peter, rev. (Guide to Polish libraries and archives), $378-79$

Kurth, William H., and Niland, "Estimating lost volumes in a university library collection," 128-36

\section{L}

Ladd, Dorothy P., rev. (Managing the catalog department) 281-82

LaHood, Charles G. and Sullivan, Robert C., Reprographic services in libraries, rev. of 569-70

Laird, W. David, rev. (Information for action), 566-68

Landmarks of library literature. 1876-1976, Ellsworth and Stevens, eds., rev. of, 568-69

Leach, Steven, "The growth rates of major academic libraries: Rider and Purdue reviewed," $531-42$

Learning resource centers in community colleges: a survey of budgets and services, Thomson, rev of $79-80$

"Letter to ACRL EBSS members," Gossage, n31-32

Letters, 167; 369-72; 551-52; n57; n114; n188; n252

Lewanski, Richard C. comp. Guide to Polish libraries and archives, rev, of, 378-79

Lewis, Felice Flanery, Literature, obscenity o law, rev. of, 566

Libraries and archives in Germany, Welsch, rev, of, 470-71

Libraries and the challenge of change, Ingram and Jefferson, eds., rev. of. 184-85

Libraries and work sampling, Goodell, rev. of, 175

Libraries in higher education: the user approach to service, Cowley, rev. of, 277
Library automation systems, Salmon, rev. of, 374-75

Library automation: the state of the art $I I$, Martin and Butler, eds., rev. of, 375-77

Library management cases, Lowell, rev. of, 380

Library networks '74-75, Goldstein, ed, rev, of, 76-77

The Library of Congress as the national bibliographic center, rev. of, 562

"Library services to the graduate community: introduction," Smith, 246

"Library services to the graduate community: the role of the subject specialist librarian," Michalak, 257-65

"Library services to the graduate community: the University of California, Berkeley," Lipow, 252-56

"Library services to the graduate community: the University of Michigan," Dunlap, 247-51

Line, Maurice B., rev. (Farewell to Alexandria), $556-58$

Line, Maurice B., and Barr, eds., Essays on information and libraries, rev, of, 275-76

Lipow, Anne Grodzins, "Library services to the graduate community: the University of California, Berkeley," 252-56

Literature, obscenity \& law, Lewis, rev. of, 566

"The literature of participation: from optimism to realism " Kaplan ( $C \& R L$ 36:473-79), comment, 369-71; respcnse, 371

Lowell, Mildred Hawksworth, Library management cases, rev. of, 380

Lunati, Rinaldo, Book selection: principles and procedures, rev. of, 379-80

Lydenberg, Harry Miller, port., 339

Lynch, Beverly, resignation \& port., n299

\section{$\mathrm{M}$}

McClure, Charles $\mathrm{R}$, rev. (Norton on archives), 186

McDonald, Dennis D., and Chisholm, eds, Reader in media, technology and libraries, rev. of, 563

McDonald, Joseph, letter to the ed., $\mathrm{n} 252$

McElderry, Stanley, "Readers and resources: public services in academic and research libraries, 1876-1976," 408-20

McGarry, K. J., Communication knowledge and the libratian, rev. of, 182

McGill, Michael J., rev, (Document retrieval systems), 181-82

McInnes, D., and Stuart-Stubbs Friesen, Interlibrary loan in Canada: a report of a survey. rev. of, $572-73$

McInnes, D., and Stuart-Stubbs; Nichol; Friesen, $A$ survey and interpretation of the literature of interlibrary loan, rev. of, $572-73$

McLean, Eva, and Zell; Oluwasanmi, Publishing in Africa in the seventies, rev, of, 280

Madden, Henry Miller, rev. (Censure and censorship), 78; rev. (The flight from reason), 7778

Maier, Kurt S., rev, (Libraries and archives in Germany), 470 - 
Managing the catalog department, Foster, rev. of, 281-82

"Managing the public service institution," Drucker, 4-14

Manual of business library practice, Campbell, ed. rev. of, 473-74

Marchant, M. P., letter to the ed., 369-71; response, 371

Markuson, Barbara Evans, rev. (Handbook of data processing for libraries, $2 \mathrm{~d}$ ed.) 170-71

Marshall, Joan K., and Sellen, eds., Women in a woman's profession: strategies, rev. of, 74 76

Martin, Susan K., and Butler, Brett, eds., Library automation: the state of the art II, rev. of, 375-77

Media in higher education, the critical issues: ideas, analysis, confrontation, rev. of, 564-65

Meetings, n1I-13; n36-41; n61-

70 ; n87-92; nl19-21; n 139 44; n177-81; n206-8; n238$40 ; n 276-80 ; n 308-10$

Metcalf, Keyes D., port, 346; "Six influential academic and research librarians," $332-45$

Metcalfe, John, Information retrieval, British \& American, 1876-1976, rev. of, 479-80

Michalak, Thomas J., "Library services to the graduate community: the role of the subject specialist librarian," 257-65

Microforms in libraries: a reader, Diaz, ed, rev, of, 81-82

Milczewski, Marion A., rev, (Es says on information and libraries), 275-76

Miller. Rush G., "The influx of Ph.D.s into librarianship: intrusion or transfusion?" 158-65

Modern archives and manuscripts: a select bibliography, Evans, comp., rev. of, 478-79

Modern manuscripts: a practical manual for their management. care and use, Duckett, rev. of, 276-77

Montague, Eleanor, rev. (Library automation systems), 374-75

Montgomery, Leon, Document retrieval systems: factors affecting search time, rev. of, 181 82

Moore, Everett T., retired, n225

Moore, J. R., rev. (Classification and indexing in science, 3d ed. ) , 179-80

Mount, Ellis, University science and engineering libraries: their operation, collections, and facilities, rev, of, 185-86

Murdock, Lindsay, and Opello, "Acquisitions overkill in science collections - and an alternative," 452-56

Myers. Margaret, and Scarborough, Mayra, eds. Women in librarianship: Melvil's rib symposium, rev, of, 74-76

Myrick, William J., Jr., Coordination: concept or reality? $A$ study of libraries in a university system, rev. of, 469-70

\section{$\mathrm{N}$}

"NELINET-ACRL/NEC joint meeting and conference," Seuss, n3-6

"National catalog of Asian materials needed," conference report, Sharma (CURL News $36: 345-46)$, correction, n55

National Center for Educational Statistics, "Academic library statistics released for 1974-75," n57

New, Peter G., Reprography for librarians, rev, of, 569-70

New England Academic Librarians' Writing Seminar, n280

The new library key, $3 \mathrm{~d}$ ed., Cook, rev. of, 278-80

"Newcomer to the academic scene: the two-year college library/learning center," Wallace, 503-13

News from the chapters, n5; n34; n57; n114; n158; n303

News from the field, n8-22; n3546; n59-72; n86-93; n1 15-26; n139-53; n174-88; n202-18; n235-51; n274-88; n306-18

Nichol, K., and Friesen; McInnes; Stuart-Stubbs, $A$ survey and interpretation of the literature of interlibrary loan, rev. of, 57273

Niland, Powell, and Kurth, William H., "Estimating lost volumes in a university library collection," 128-36

Nitecki, Joseph Z., rev. (The sourcebook of library technol$o g y, 1976$ ed. ) , 558-61

Norton, Margaret Cross, Norton on archives: the writings of Margaret Cross Norton on archival \& records management, rev, of, 186

Norton on archives: the writings of Margaret Cross Norton on archival \& records management, Norton, rev, of, 186

\section{0}

Oboler, Eli M. rev. (Literature, obscenity \& law), 566

O'Connell, Merrilyn Rogers, and Rath, eds., Historic preservation, rev. of 378

OCLC instructional videotapes, n278

Olevnik, Peter P., rev. (Evaluating library use instruction), $280-81$

Oluwasanmi, Edwina and McLean, Eva; Zell, Hans, Publishing in Africa in the seventies, rev, of, 280

Opello, Olivia, and Murdock Lindsay, "Acquisitions overkill in science collections-and an alternative," 452-56

"Open shelves/closed shelves in research libraries," Rovelstad, 457-67

"Organizational patterns in academic libraries, 1876-1976," Dunlap, 395-407

Orlando, Thomas A., prof. \& port., $\mathbf{n} 23$

Orne, Jerrold, "Academic librarv buildings: a century in review," 316-31

O'Rourke, James R., Sr., retired, n95

Other publications of interest to academic librarians, $82-86$. $187-89 ; 282-84 ; 380-83 ; 575-$ 79

"An overview of ARL directors, 1933-1973," Cohn, 137-44

\section{$\mathrm{P}$}

Panofsky, Hans E., A bibliography of Africana, rev. of ( $C \& R L$ 36:519-20), comment. 167. response, 167: rev, (Publishing in Africa in the seventies), 280
Parks, James F., Jr., rev. (Reference as the promotion of free inquiry), 573-74

Parr, Mary, and Harvey, "University library search and screen committees," 347-55; comment, 551; response, 551-52

Peet, Helen, retired, n324

People, n23-25; n47; n75-77; n95; n127-28; n159-61; n191; n223-25; n259-61; n291-92. n323-24

Peterson, Kenneth G., prof. \& port., $n 23$

Pickett, Steve, retired, n261

Piternick, George, rev. (The Library of Congress as the national bibliographic center), 562

Poole, William Frederick, port., 332

Pratt, Barbara, retired, n225

Profiles, n23; n127; n223-24; n259

Public libraries as culture and social centers: the origin of the concept, Davies, rev. of, 175 76

Publications, n20-22; n45-46; n71-72; n92-93; n121-26; n148-53; n185-88; n212-18; n245-51; n281-88; n311-18

Publishing in Africa in the seventies, Oluwasanmi, McLean and Zell, rev. of, 280

Putnam, Herbert, port, 335

\section{Q, R}

Rare book librarianship, Cave, rev, of, 476-77

Rath, Frederick L., Jr., and O'Connell, Merrilyn Ṙogers, eds., Historic preservation, rev. of, 378

Reader in library technology, Adamovich, ed., rev, of, 478

Reader in media, technology and libraries, Chisholm and McDonald, eds., rev, of, 563

"Readers and resources: public services in academic and research libraries, 1876-1976,' McElderry, 408-20

"Reading, writing," Johnson, editorial, 109

Recent publications, 71-89; 169 92: 275-84; 373-87; 469-80; 555-82

Reference as the promotion of free inquiry, Shores, rev, of. $573-74$

Regnier, Flora D., "Copyright law -1976," n171-72

Reid, Marion T., "Coping with hudget adversity: the impact of the financial squeeze on acquisitions." 266-72

"Renewable resources program for ABSS," ACRL, Agriculture and Biological Sciences Section, $\mathbf{n} 138$

Reprographic management handbook, Crix, rev. of, 569-70

Reprographic services in libraries. LaHood and Sullivan, rev, of, 569-70

Reprography for librarians, New, rev. of, 569-70

"Resolution on racism \& sexism awareness," ALA, n287

Retirements, n25; n47; n95; n161; n191; n225; n261; n292; n324

"Retrenchment in higher education: implications for libraries," ACRL. Eastern New York Chapter. n6-7; videotape available, n 275 
"Richard Gilman Folsom Library dedicated," n170

Richardson, Ermest Cushing port., 524

Robinson Otis Hall, port. 29

Rochell, Carlton C., prof. \& port., n223

"The role of the academic librarian, 1876-1976," Downs, 491502

The role of the beginning librarian in university libraries, Edwards, rev. of, 477-78

Rouse, Roscoe, rev. (Guide to the research collections of the New York Public Library) 373-74

Rovelstad, Mathilde $V_{\text {, " "Open }}$ shelves/closed shelves in research libraries," 457-67

Rudolph, G. A., rev. (Library management cases), 380

\section{S}

"Salaries of academic librarians 1975/76," ACRL, n231-34

Salmon, Stephen R., Library automation systems, rev. of, 374 75

Scarborough, Mayra, and Myers. eds. Women in librarianship. Melvil's rib symposium, rev. of, 74-76

Schlipf, Frederick A., ed., Collective bargaining in libraries, rev. of. 377

Schmidt, C. James, "Collective bargaining and academic librarians: a review of the decisions of the NLRB," nl-3

Scott, Edith, rev. (The age of Jewett) 174-75

Seely. Elizabeth Caven, deceased, n128

"Selected reference books of 1974-75," Sheehy, 60-69

'Selected reference books of 1975-76," Sheehy, 356-67

Sellen, Betty-Carol, and Marshall, Joan K., eds., Women in a woman's profession: strategies, rev, of, 74-76

"Serial cuts vs. public service: a formula," Holland, 543-48

Seuss, Jacqueline, "NELINETACRL/NEC joint meeting and conference," n3-6

Shackleton, Robert, Censure and censorship: impediments to free publication in the Age of $\mathrm{En}$ lightenment, rev. of 78

The shaping of American library education, Churchwell, rev. of, $173-74$

Sharma, Ravindra N., "National catalog of Asian materials needed," conference report (C\&RL News 36:345 46), correction $\mathbf{n 5 5}$

Sheehy, Eugene P.. "Selected reference books of 1974-75,"6069: "Selected reference books of 1975-76," 356-67

Sheridan, Leslie W., rev, (The role of the beginning librarian in university libraries), 477-78

Sherrod, John ed, Information systems and networks. Eleventh annual symposium, March 2729,1974 , rev, of, 82

Shore, Della, retired, n225

Shores, Louis, Reference as the promation of free inquiry, rev. of, $573-74$

Silberstein, Stephen M., rev. (Annual review of information science and technology, v.10, 1975), 56I-62
Simonson, Emma, retired, n225

Simpson, Frances, retired, n324

"Six intluential academic and research librarians," Metcalf $332-45$

Smith Eldred R., "Library services to the graduate community: introduction," 246

Smith, Jessie Carney, rev. (Black literature resources), 47 I-72

Smith, Martha Frances, retired, n25

"Some effects of faculty status on supervision in academic libraries," Bailey, 48-52

The sourcebook of library tech nology: a cumulative edition of library technology reports 1965-1975, $1976 \mathrm{ed}$, rev. of $558-61$

Spang, Lothar, rev. (Collective bargaining in libraries), 377

Specialised information centres, Harvey, rev. of, 473-74

Spreitzer, Francis F., rev. (Reprographic management handbook), 569-70; rev. (Reprographic services in libraries), 569-70; rev. (Reprography for librarians, 569-70

Standards for library service: an international survey, Withers, rev. of, $78-79$

"Statement on access to original research materials in libraries. archives, and manuscript repositories," ACRL, Rare Books and Manuscripts Section, Committee on Manuscripts Collections ( $C \& R L$ News 35:114), proposed revisions, 99-101; approved statement n272-73

"Statement on faculty status of college and university librarians," ACRL/AAC/AAUP (C⿺RL News 35:26), "Organizations endorsing the statement on faculty status," n33. endorsement, n311

"Statement on the reproduction of manuscripts and archives for noncommercial purposes," ACRL, Rare Books and Manuscripts Section, Committee on Manuscripts Collections ( $C \& R L$ News 35:115), proposed revisions, n102-4; approved statement, $\mathbf{n} 271$

Stecher, Elizabeth, Catalogue provision in libraries of colleges of advanced education, rev. of 568

Stevens, Florence, retired, n324

Stevens, Norman D. and Ellsworth, eds. Landmarks of library literature, 1876-1976. rev. of 568-69

Strauss, L. Harry, retired, n261

Strozik, Teresa, rev. (Library automation), 375-77

Stuart-Stubbs, B. and Friesen, M.; McInnes, D., Interlibrary loan in Canada: a report of a survey, rev, of, 572-73

Stuart-Stubbs, B., and Nichol, K. Friesen, M.; McInnes, D., A survey and interpretation of the literature of interlibrary loan, rev, of, 572-73

Stueart, Robert D., "Writing the journal article," 153-57

Stuff, Marjorie Ann, retired, n324

Sullivan, Robert C., and LaHood, Reprographic services in libraries, rev. of, $569-70$

A survey and interpretation of the literature of interlibrary loan. Stuart-Stubbs, Nichol. Friesen and McInnes, rev. of, 572-73

Talbot, Richard J., rev, (Information revolution), 474-75 rev. (Information roundup) 474-75

Tallman, Johanna E., rev. (University science and engineering libraries), 185-86

Tatum, G. Marvin, Jr., and Edelman, "The development of collections in American university libraries," 222-45

Tharpe, Josephine, retired, $\mathbf{n} 25$

Thomas, J. Luther, deceased, n77

Thompson, Anthony Hugh, Censorship in public libraries in the United Kingdom during the twentieth century, rev. of, 565 66

Thomson, Sarah Katharine, Interlibrary loan policies directory. rev, of ( $C \& R L$ 36:429), comment, 167; Learning resource centers in community colleges. a survey of budgets and services, rev, of 79-80

"To enlarge the sphere of human knowledge': the role of the independent research library," Budington, 299-315; comment, 552

Tolan, Edwin K, deceased, n128

Totter, Herman L., and Cassata, eds., The administrative aspects of education for librarianship: a symposium, rev. of, 180-81

Toy, Emest W. Jr. rev, (Communication, knowledge and the librarian), 182

Treasures from the Bodleian Library, Hassall and Hassall, rev. of $570-72$

Tuttle, Helen W., "From Cutter to computer: technical services in academic and research libraries, 1876-1976," 421-51

\section{U}

Uberregionale Literaturversorgung oon Wissenchaft und Forschung in der Bundesrepublik Deutschland: Denkschrift, German Research Society, Lihrary Committee, rev. of, 182-83

"University library search and screen committees," Harvey and Parr, 347-55; comment 551; response, 551-52

University science and engineering libraries: their operation. collections. and facilities. Mount, rev. of, 185-86

Use of reports literature, Auger, ed., rev. of, 178-79

\section{V}

Veit, Fritz, The community college library, rev. of, 183-84

Verona, Eva, Corporate headings: their use in library catalogues and national bibliographies, rev. of, 480

Vickery, B. C., Classification and indexing in science, $3 \mathrm{~d}$ ed., rev. of, $179-80$

Vinton, Frederic, port. 32

Voigt, Melvin J., retired. n261

Vosper, Robert, "A century abroad," 514-30

\section{W}

Wadsworth, Robert Woodman rev. (Books for college libraties), 71-74

Wahoski, Helen, retired, $n 47$ 
Walch, David B., rev. (Reader in media, technology and libraries), 563

Walker, Gay, rev. (Historic preservation), 378

Walker, John F., and Kohut, "Allocating the book budget: equity and economic efficiency" ( $C$ dRL 36:403-10), comment, 369

Wallace, James O., "Newcomer to the academic scene: the twoyear college library/learning center," 503-13; rev. (Learning resource centers in community colleges), 79-80

Walton, Clyde C. rev. (Modern manuscripts), 276-77

Weber, David C., "A century of cooperative programs among academic libraries," 205-21. "Keyes D. Metcalf," 346

Weiss, William, appt., n300
Welsch, Erwin K., Libraries and archives in Germany, rev. of, 470-71; rev. (Oberregionale Literaturversorgung von Wissenschaft und Forschung in der Bundesrepublik Deutschland), 182-83

Wiegand, Wayne A., rev. (Information retrieval, British o American, 1876-1976), 47980

Williams, Sam P. comp., Guide to the research collections of the New York Public Library, rev, of, 373-74

Williamson, Charles Clarence, port., 343

Winger, Howard W., rev. (Treasures from the Bodleian Library), 570-72

Winsor, Justin, ports., $31 ; 335$

Withers, F. N., Standards for li- brary service: an international survey, rev. of, 78-79

Women in a woman's profession: strategies, Sellen and Marshall, eds., rev. of , 74-76

Women in librarianship: Melvil's rib symposium, Myers and Scarborough, eds., rev. of, 7476

World trends in library education, Bramley, rev. of, 171-73

Writing seminar, n280

"Writing the journal article," Stueart, 153-57

Wynn, G. Richard, port., n7

$$
\mathrm{X}, \mathrm{Y}, \mathrm{Z}
$$

X, Laura, Letter to the ed., $\mathbf{5 5 2}$ Zell, Hans, and Oluwasanmi; McLean. Publishing in Africa in the seventies, rev, of, 280

Zernov, Vladimir, deceased, n161

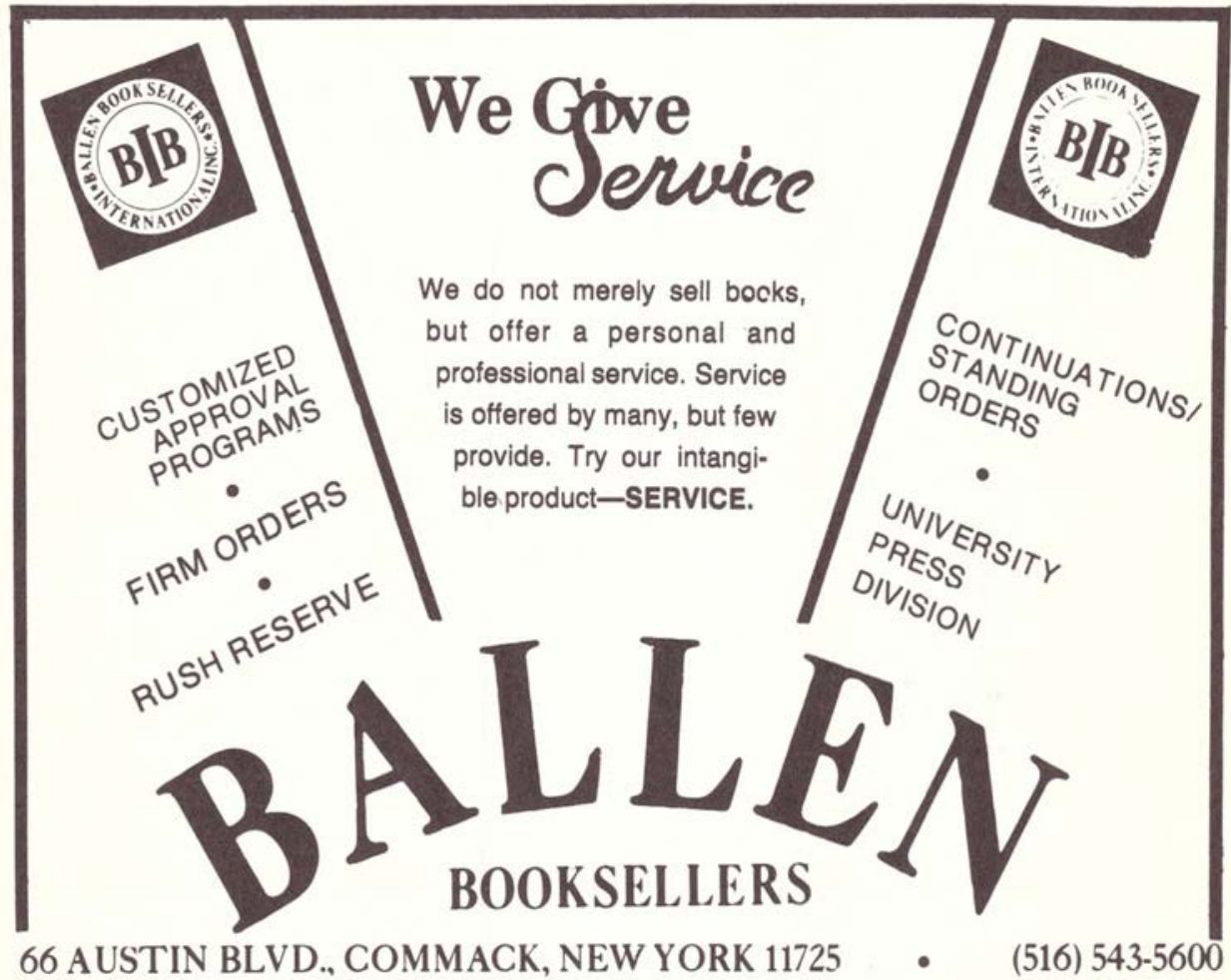




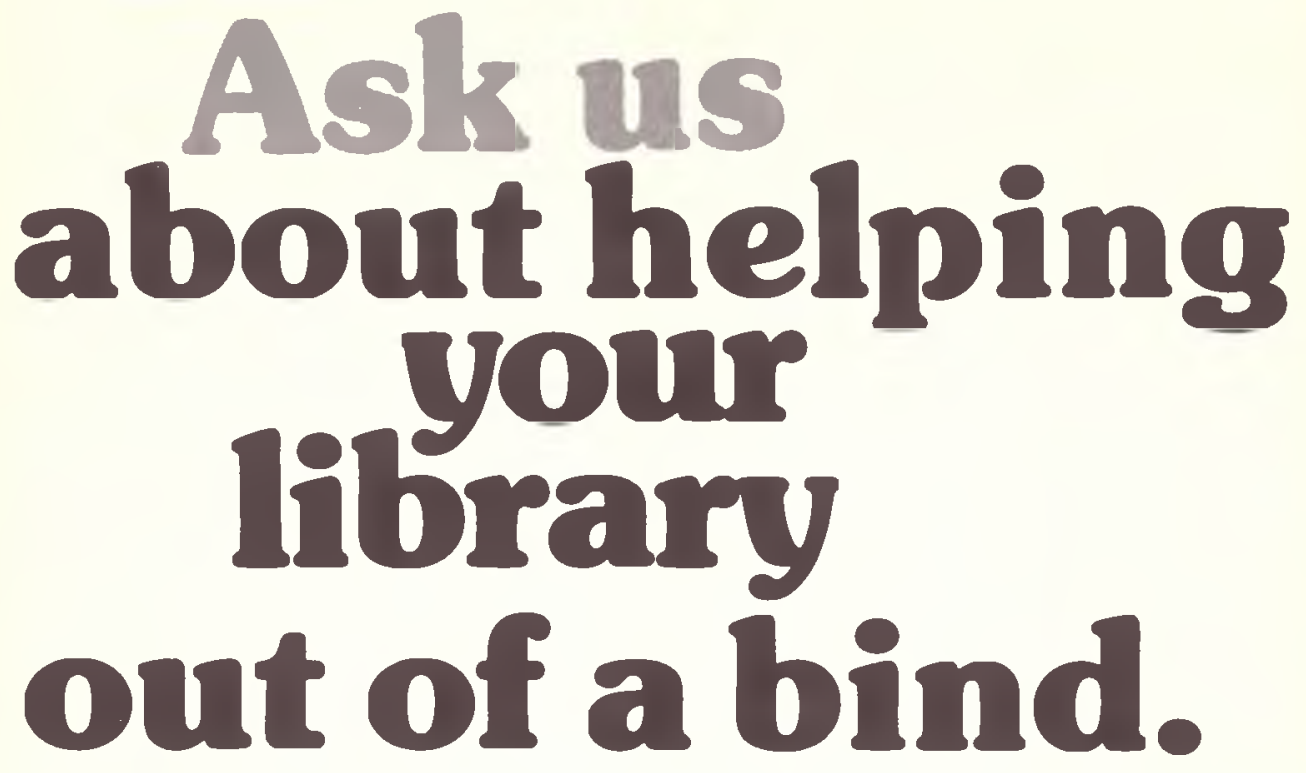

The problems with bound face...microform...a product periodicals never seem to end. that saves space in your library As the demand for more in- and money in your budget. In formation continues to grow. fact, microform requires up to you need more and more $95 \%$ less storage space than space to store it. Then there are bound periodicals, while greatly the added problems of muti- reducing the risks of mutilation lation and loss, too.

How do you get out of this bind? Ask us. University Microfilms International offers an answer to the problems libraries

What does this mean for your library? Ask us. University Microfilms has now packaged all the advantages of microform
Subscription Service. This remarkable service automatically ensures the latest volume of any given title as soon as it is available in microform, usually six months to a year following publication. The Serials Subscription Service offers over 7,000 titles, including many of the most popular titles, with guaranteed annual prices and only one invoice with your order for the entire year.
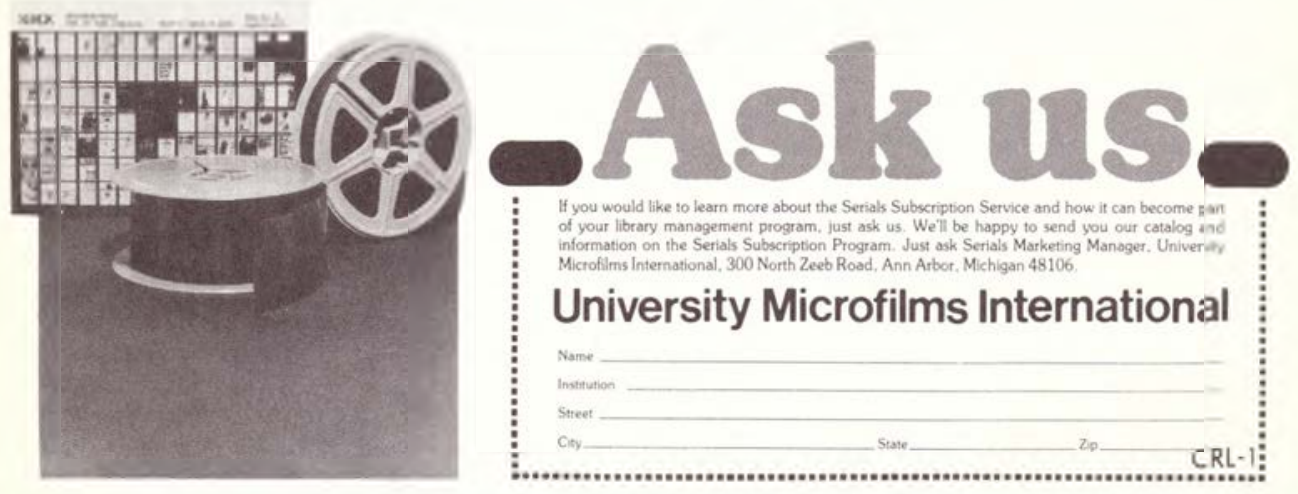
into a program called the Serials

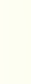


state Commission on Higher Education, P.O. Drawer P, Boulder, CO 80302; (303) 4927317 or $492-8188$.

- The University of Illinois Graduate School of Library Science will sponsor a four-week course at the Newberry Library in Chicago from Monday, July 11, through Friday, August 5, on "The Conservation of Research LIBRary Materials." The course has been offered in alternate years since 1971 and will be taught by Paul N. Banks, conservator of the Newberry Library since 1964.

Designed for those who are responsible for the physical care of rare, research-type books and manuscripts, this course emphasizes the considerations involved in making decisions about the care of collections. It is not a workshop course in restoration or book repair. The class will meet at the Newberry Library, $60 \mathrm{~W}$. Walton St., Chicago, for four hours a day, four days a week, with field trips on the fifth day.

Tuition will be $\$ 88$, and the course carries one unit of graduate credit.

For an application for admission and for information on housing, write Richard F. Casper, University of Illinois Office of Continuing Education, 300 W. Golf Rd., Mt. Prospect, IL 60056 , (312) 255-3320.

- The University of Illinois Graduate School of Library Science will offer a course on "MEDical Literature and Repenence Work" in the 1977 summer session from Monday, June 20 , through Friday, July 22. The instructor will be Professor Lorraine Hirschfeld, head of information services, Library of the Health Sciences, University of Illinois Medical Center, Chicago.

Detailed consideration will be given to bibliographical and reference materials in the health sciences (dentistry, pharmacy, public health, etc.) including government documents, computerized retrieval systems, and audiovisual materials. Course assignments will include visits to nearby medical and scientific libraries, hands-on experience with Medline, and practical problems utilizing typical reference sources.

The course carries one unit of graduate credit, and the tuition will be $\$ 88$. Housing is available in dormitories on the medical center campus. For further information or an application blank write Richard F. Casper, Office of Continuing Education, University of Illinois, 300 W. Golf Rd., Mt. Prospect, IL 60056, (312) 25.5-3320.

\section{PUBLICATIONS}

- Arabic Historical Writing, 1974: An Annotated Bibliography of Books in History from All Parts of the Arab World, compiled and annotated by Fawzi Abdulrazak, intern (Arabic specialist) in the Middle Eastern Department of the Harvard College Library, recently has been published by the Harvard University Library. Mr. Abdulrazak's Arabic Historical Writing, 1973 appeared last year, and compilation of a volume for 1975 is currently under way.

- The resources of 290 Virginia libraries are described in A Directory of Virginia Library Resources, compiled by the Task Force on Library Resources of the State Council of Higher Education for Virginia. The entry for each library consists of a description of identified resources, including collection size, subject strengths, and special collections, as well as a statement of service policies and means of access. Use of the directory is enhanced by three indexes: an index of institution or corporate names, an index of special collections (including many manuscript and nonprint holdings), and an index of subjects. It is particularly valuable for the many U.S. government agency libraries that are listed. The 245-page directory is available free of charge from: John E. Molnar, Library Planning Coordinator, State Council of Higher Education for Virginia, 700 Fidelity Building, 9th and Main Streets, Richmond, VA 23219.

\section{Personalized service... automatically}

Faxon's automation means even more than computer speed and accuracy. It means systems designed to make Faxon customers virtual experts in subscription management.

Faxon's new SCOPE Service enables libraries to monitor price increases over a three-year period by taking price data directly from their unique personal history files stored in Faxon's computer. SCOPE is ideal for department heads and subject specialists who can make a thorough review of subscription costs as they relate to budgets prior to annual renewal.

Serials control information is also available from Faxon's computer on either punched cards or magnetic tape. Libraries with data processing capabilities will find our input precise and time-saving.

Faxon makes automation work for you .... personally.

\section{f.U. faXON COMPAnY,IIIC. \\ Library Magazine Subscription Agency \\ 15 Southwest Park, Westwood, MA 02090 Tel: 800-225-7894 (toll-free) \\ 617-320-3350 (collect in Mass and Canada only)}


- The Canadian Library Association's microfilm program has been very active since November 1947. Since its beginning, 232 Canadian newspapers have been filmed spanning the years from 1752 to 1928 . Also 27 periodicals, journals, and studies have been microfilmed.

In early 1973, there was some indication that provincial studies were about to assume a place of importance in Canadian scholarship. For this reason, a microfilm program entitled Early Provincial Government Documents on Microfilm was begun.

The first phase of the provincial document filming has now been completed and covers the period from .1867 to 1900 . The microfilm includes legislative assembly and council journals, which recorded the business of each session; sessional papers (departmental reports); statutes and revised statutes (laws); and debates and proceedings. Phase 2 (1901-1920) is now in progress.

The list of provincial government documents is available from the Microfilm Program of the Canadian Library Association, 151 Sparks St., Ottawa, Ontario. Prices quoted are for complete provincial sets. However, individual reels may be purchased for $\$ 30$ each.

- The Continuing Library Education Network and Exchange (CLENE) has published a final report of its activities during the year of its funding by the U.S. Office of Education. From June 15, 1975, to June 30, 1976, CLENE operated under a planning grant from the Office of Libraries and Learning Resources, Title II-B fund from the Higher Education Act. The year of planning included four major objectives: creation of a permanent administrative structure for CLENE; establishment of a dues and fees structure; development of operational mechanisms required for the implementation of CLENE; identification of funding sources and preparation of proposals. The final report summarizes what CLENE has achieved in light of these four objectives.

Some of the major achievements are:

1. A computer-based information network that gives information, in print or on-line, aboit continuing education opportunities - their content, location, time, objectives, costs, leadership.

2. A directory of CLENE members that helps to find the leaders with the expertise, experience, and education to support continuing education programs.

3. Two CLENE Assemblies, with published proceedings, which have sought to develop innovative solutions to national concerns related to continuing education.

4. The CLENExchange newsletter to keep readers current on what's happening in continuing education circles.
5. A continuing, multiprofessional, annotated bibliography that gives users a quick way of pinpointing resources to assist them in solving their problems.

6. A network of persons concerned about continuing education from a wide array of organizations and institutions with whom to share ideas and creative approaches to continuing education issues.

7. Concept papers on planning and teaching continuing education courses and on evaluating programs.

Included in the report are an evaluation of the significant aspects of the program as presented by the Panel of Review and Evaluation; a program review and planning structure for CLENE as prepared by the $1975 / 1976$ ad hoc board of directors for the newly elected 1976/1977 board of directors; conclusions and recommendations by the project staff. An appendix includes selected items of particular relevance generated during the project year.

The final report is available from the CLENE Office, Box 1228, 620 Michigan Ave., N.E., Washington, D.C. 20064 at a cost of $\$ 2$ for members and $\$ 3$ for nonmembers.

- Selected Sound Recordings of American, British, and European Literature in English is a 140-page publication with 1,365 main entries of cassette tapes and disc records from 53 sources. The University Libraries at the University of Toledo announce the availability of this catalog, which is divided into 12 subject areas including Elizabethan drama, European drama, and American poetry. Unique is the fact that the titles of individual poems are listed for each recording. The compiler, Dr. Homer E. Salley, director of the Technological Media Center, has also reported purchasing information for each item: author, title, order number, distributor's name and address. Playing time or duration is given for about 85 percent of the entries. When available, dates are given for the recording and for the original publication of the work.

The recordings are of five types: dramatizations of plays and novels, including highlights; readings by the author; readings by professional talent (e.g., James Mason, Judith Anderson); discussions of literary works by teachers and critics (e.g., Gilbert Highet, Philip Young); sound tracks from films.

The publication is available for $\$ 10$. Send orders with payment to: Technological Media Center, University of Toledo, 2801 W. Bancroft St., Toledo, OH 43606.

- G. K. Hall \& Co. announces the publication of Catalogues of the United Kingdom Department of the Environment Library, London, England, an outstanding reference source for the study of the environment. These catalogs are photographic reproductions of the library 
cards of the Department of the Environment Library in book form.

Formed by the amalgamation of the Library of the Ministry of Housing and Local Government and the Library of the Ministry of Transport, the Department of the Environment Library is one of the largest collections of its kind in the world. Approximately 250,000 books, pamphlets, and government reports, and some 2,500 current periodicals provide rich source material on all subjects pertaining to the environment.

The catalogs of the library contain approximately 580,000 bibliographic entries, offering access by author and by subject to the wealth of material in the collection. Major subject areas covered by the literature include social and environmental planning; roads, traffic, and transport; countryside and recreation; housing and local government; new towns, water, sewerage, and public hygiene; and pollution. The collection is particularly strong in postwar planning material. The scope of the collection ranges from early 19th-century local government reports to recent information on economic, parliamentary, statistical, scientific, and technical aspects of pollution.

Information about this outstanding resource may be obtained from G. K. Hall \& Co., 70 Lincoln St., Boston, MA 02111, (617) 4233990.

- Statistical Sources on the History of France, a collection of nearly 100 extremely rare statistical works from the period of the French Revolution and the Empire has been published on microfiche by Microéditions Hachette and is being distributed in North America by Clearwater Publishing Company, 75 Rockefeller Plaza, New York, NY 10019.

Most of the titles in the collection are the responses of the various French prefects of the period to questionnaires sent from Paris. These works provide detailed statistics on the industry, agriculture, topography, demography, and health of the districts. Few libraries in the world, even in France, contain very many of the originals, including the British Museum and the Library of Congress. The collection was filmed by the Bibliothèque Nationale.

A list of the titles in the collection is available free of charge from Clearwater. The price of the complete collection is $\$ 950$, from inventory in New York.

- WILCO (Western Interstate Library Coordinating Organization) is making available for general distribution and comment the fifth draft of Library Networking in the West: The Next Three Years. The document, originally prepared by WILCO staff, has been extensively reviewed and revised by representatives from bibliographic utilities, service centers, state library agencies, academic and public libraries, and others in the library and information science profession.

The document discusses goals for networking in the West (in the context of national library network planning) that can guide resourcesharing activities during the next three years, including a strategy, tasks, and responsibilities for each. The document is not a task list for WILCO or any single organization. It is a guide to which western librarians can contribute and commit as they all move forward in making cooperation more effective in the West and the country. Over the next several months, work can be started on each task. For a free copy, contact: Mary Haenselman, Project Secretary, WILCO, P.O. Drawer P, Boulder, CO 80302, (303) 492-7317.

This network-planning document must be dynamic in order to continually take into account national network planning, technological advancements, and comments from librarians and information scientists. WILCO welcomes comments and reactions and will issue new drafts as required. Please send comments to Eleanor Montague or Karl Pearson at the above address.

- The School of Library Service, Dalhousie University, has published its Occasional $\mathrm{Pa}$ per No. 12. Entitled The Helen F. Macrae Collection, a Bibliography of Korea Relations with Canadians and other Western Peoples, it includes a checklist of documents and reports, 1898-1975.

- The Library of the University of California at Berkeley has announced the publication of a new reference work on microfiche: the Berkeley Serials Union List (ISSN: 03637026). Published each month and continually updating the more than 210,000 titles held by the 41 libraries on the Berkeley campus, it is available as a subscription. Contact: The Librarians Office, General Library, University of California, Berkeley, CA 94720.

- ERIC announces the publication of a free microfiche: Looking forward to 1976: A Selected Bibliography on the Functions and Contributions of Libraries in American Society, prepared for 1975 Annual Convention of the American Library Association by the Stanford Libraries and the ERIC Clearinghouse on Information Resources.

This is available from: Eric Clearinghouse on Information Resources, Stanford Center for Research and Development in Teaching, Stanford University, Stanford, CA 94304. They have also published a set of 25 slides about ERIC with accompanying booklet $(1976, \$ 20)$ covering: Introduction to ERIC, the Thesaurus, Resources in Education, Current Index to Journals in Education, and Computer Search Strate- 
gy. This can be used to teach a variety of audiences having different levels of sophistication. Send check payable to "Box E" to Box E, School of Education, Stanford University, Stanford, CA 94305 .

- R. R. Bowker Company announces simultaneous publication of all seven volumes of the 13th edition of American Men and Women of Science edited by Jaques Cattell Press. Publication date was October 29, 1976, marking 70 years since the inception of the one-volume first edition of the biographical directory of active scientists of North America. Reflecting on certain pivotal events in the development of three companies now part of the same corporate family, Jaques Cattell Press, R. R. Bowker Company, and Xerox Corporation, the year 1906 appears to have been an auspicious one.

- Peter Martin Associates has announced the publication of the first edition of Canadian Book Review Annual and Canadian Fiction: An Annotated Bibliography.

Canadian Book Review Annual was conceived and prepared under the editorial direction of Dean Tudor, chairman of the Library Arts Department, Ryerson Polytechnical Institute, Toronto. CBRA provides reviews by librarians and subject specialists of all Canadian English-language trade titles published in 1975, including 1975 reprints of titles originally pub- lished before 1966, selected federal and provincial government publications, and English translations of French-Canadian titles. The concise 250-word reviews are organized by number within subject categories and provide complete ordering and bibliographical information (author, title, publisher, place and date of publication, collation, price, and ISBN).

Says Dean Tudor, "CBRA will be the basic selection aid for school, college, and university librarians, not only in Canada but abroad."

Canadian Fiction: An Annotated Bibliography fills the need for a comprehensive bibliographical guide to Canada's literature. Every novel and short story collection (including translations of French-Canadian titles) is listed with a concise descriptive annotation. Each author entry lists out-of-print titles, critical and biographical studies, as well as relevant multimedia material. An invaluable index groups fiction titles under the major thematic areas of Canadian literature.

- Information Resources Press announces a new abstracting and indexing periodical, EIS: Key to Environmental Impact Statements. It indexes environmental impact statements by subject content, geographic area involved or affected, and by originating agency or organization. For further information contact: IRP, 2100 M Street N.W., Suite 316, Washington, D.C. 20037.
PROFILES

Eldren R. Smith has been appointed director of university libraries and professor at the University of Minnesota, according to a recent announcement issued by University President C. Peter Magrath. The appointment was effective in December. Mr. Smith has been, for the past four years, director of university libraries and professor at the State University of New York at Buffalo.

At Minnesota, Mr. Smith will have direct responsibility for the administration of the Twin Cities campuses library system, which has combined holdings in excess of three million volumes, as well as a substantial manuscript and archives collection. In addition to these rich resources, the University of Minnesota Libraries are particularly known for the pioneering role that they have played in significant cooperative developments (the Midwest Interlibrary Center, MINNITEX, and CONSER) and in academic library governance.

A graduate of the University of California at Berkeley, Mr. Smith earned a M.A. in English from that institution, as well as a MSLS from the University of Southern California. He has held positions in several academic libraries, including those at Long Beach State University, San Francisco State University, and the University of California at Berkeley. Before going to Buffalo, Mr. Smith was associate university librarian at Berkeley. He has taught at the University of Washington and at SUNY-Buffalo.

Mr. Smith has been active in a variety of professional organizations. Currently vice-president/president-elect of the Association of College and Research Libraries, he has previously served as chairman of its Academic Status Committee and its University Libraries Section. $\mathrm{He}$ is a member of the board of directors of the Center for Research Libraries. Mr. Smith has been president of the Librarians' Association of the University of California, as well as chairperson of the Western New York Library Resources Council, the Five Associated University Libraries, and the State University of New York Council of Head Librarians. He presently chairs a joint ARL/ACRL committee charged with developing university library standards. 